\title{
Protests against German electricity grid extension as a new social movement? A journey into the areas of conflict
}

\author{
Mario Neukirch
}

\begin{abstract}
Background: Among the major players in German energy politics, a broad consensus exists that one important condition for the transition to renewable energies is to expand the electricity transmission grid. More than $7000 \mathrm{~km}$ of new or extended power routes are planned, generally as overhead lines. Mainly because of local protests, many projects, however, lag behind their original timetable. The protest initiatives are often supported by concerned municipalities and districts, environmental organizations, and scientists. This paper examines the most conflicted projects and inquires whether the protests are part of a social movement.
\end{abstract}

Methods: The study aims for a better understanding of these protests. It therefore explores the opponents' action orientations and the relevant action fields. The main method is a comparative qualitative case study that is based on a document analysis. The latter was supported by quantitative considerations.

Results: Whereas homogeneity in local and regional contexts predominates, across the regions, the protests often strongly diverge in respect to their dominant frames and action orientations. This occurs in a diverse structure of action fields. If the protests are strong and fundamentally oriented, the conflicts take place mainly in state field and discursive arenas.

Conclusions: Although the grid extension protests share characteristics with the activities against war, discrimination, and nuclear power use, they are not a social movement in the narrow sense. Rather, they are a collection of single-point protests that occasionally transcend their own boundaries to take on a more coherent and unified character.

Keywords: Strategic action fields, Energy transition, Grid extension, Social movements, Actor constellations

\section{Highlights}

- As a whole, the protests are characterized by a high degree of heterogeneity.

- At regional level, the protests often display coherence.

- The structure of the conflict fields depends on the protesters' strength and their targets.

\section{Background}

Since the 1970s, the traditional energy sector has been confronted with various challenges: First, the oil crisis of

Correspondence: mario.neukirch@sowi.uni-stuttgart.de

University of Stuttgart, Institute for Social Sciences, Seidenstr. 36, 70174 Stuttgart, Germany
1973 and the problem of limited resources became an object of public debate; second, the insecurity of nuclear power, which has been demonstrated by the catastrophic accidents in Chernobyl (happened in 1986) and Fukushima (happened in 2011); and third, the growing awareness of the climate crisis since the 1990s.

In several western countries, social movements developed that strongly opposed fossil-nuclear energy [1]. Neither the disadvantages of the "old" energies nor the protests from civil society have led to radical changes, however. Although the pressure applied by these movements failed to achieve their demands, they strongly influenced the setting of political agendas: in Germany, the introduction of environmental policy, the support of renewable energy technologies (RET), and the decision

\section{Springer}


to stop nuclear power are evidences of changing institutional contexts. In the 1970s, when energy was cheap and secure, environmental aspects were mostly ignored. Today, energy also has to be "green" [2].

Following the approach of large technical systems [3], the development of infrastructure systems features strong elements of path dependency and is characterized by an inherent tendency towards growth. It seems, therefore, unsurprising that the discourse on the transition of the German energy system is focused mainly on the extension of the transmission grid and wind power plants, which are situated in windy areas of North Germany and on the open sea. Nevertheless, over the course of the late 1980s to the late 2000s, the process of transition in Germany deviated considerably from the RET development pathways taken by other countries such as the UK. During this period, the German RET sector was dominated by small and decentralized operations. Afterwards, the "old system" partly regained control over the development [4].

This resulted in overcapacities and necessitated the building of new power lines to transport the excess energy to the industrial centers. Furthermore, Germany avowed that it would phase out nuclear power by 2022 . Most atomic power plants are situated in the South of the country. To guarantee the security of supply and transport wind power to consumers, there are concrete plans for about $7000 \mathrm{~km}$ of high-voltage lines to be built or upgraded by 2022 [5, 6]. But in September 2015, only $558 \mathrm{~km}$ of high-voltage lines were in operation. Several projects have been delayed. As Bruns et al. [7] explained, this is the result of a combination of administrative problems, complicated licensing procedures, authorities lacking capacities and knowhow, problems of coordination between different administrative levels, and diverging interests of the federal government and the concerned regional authorities. Protest activities are another important factor. Citizens' initiatives have organized numerous public activities such as demonstrations, discussions, and benefit concerts. Some protest groups operate websites to provide comprehensive information on the latest developments. These protests and their forms of expression are embedded in the institutional change of the energy system: People are used to the ubiquitous presence of overhead power lines and the large pylons that carry them. In the past, complaints about power lines crossing villages were hardly noticed by the public. Today, many protest groups demand that energy should not only be produced sustainably but also transported sustainably. Citizens' initiatives and those directly affected are now often supported by diverse actors such as local and regional politicians, municipalities, environmental organizations, and scientists [8-10]. Against the background of this support and the institutional changes in the energy system, it becomes plausible that the protesters-in spite of being apparently quite powerless-might have a significant impact on the strategies and decisions of the incumbent actors.

Germany is one of the first large, industrialized countries that pledged (and started) to transition the energy system to renewable energies [11]. To manage this process of transition, it is imperative to deal with any conflicts that (may) arise. This article especially considers the constitution of new protest actors that oppose energy grid extension. The study examines cases of conflicted power line projects that are part of the first demand plan for additional grid capacity, the Energy Line Extension Act (EnLAG) [12], which was resolved by the federal government in 2009. The act stipulates the building of $22,380-\mathrm{kV}$ power lines with a total length of $1876 \mathrm{~km}$ [6]. Each of the most contested projects is behind schedule: some of them should have even been in operation since 2010 [13].

In fact, there is no conclusive agreement about what purposes the planned grid extension should fulfill. Ecologists (e.g., Friends of the Earth Germany [14, 15] and sections of Left Party [16]) criticize the extension plan as opaque as well as undemocratic and because it would perpetuate the centralized energy system, which faces increasing competition from small wind parks, solar panels, and biomass. Others demand that the plans for expansion be scaled back because the additional capacity would enable fossil-fuel power plants to stay in operation although there is enough renewable energy available [17]. Apart from this discussion on the systemic consequences of grid extension, there is another contested topic: the question of the effect of electromagnetic waves which are emitted by the power lines. Individuals who live nearby are afraid of health issues caused by them. Moreover, these people are concerned about negative effects on nature and their homes losing value [7].

At times, it can be difficult to identify the individual reasons for protest. In any case, a powerful sociopolitical mainstream is convinced that the planned grid extension is the only way to allow the integration of large amounts of renewable energy in the electricity system. For that reason, there is always a tendency to accuse protesters of a NIMBY attitude (not-in-my-backyard) for hampering the process of transition to RET [8]; but grid extension is a complex issue. In terms of local conflicts over new transmission power lines in the UK, Batel and DevineWright [18] showed that the NIMBY category disparages protesters. Rather, the protesters should be seen as "energy citizens" motivated not only by personal but also general concerns regarding grid extension.

The following article considers the contested field of power grid extension in Germany from such a holistic point of view: looking at several local protest sites, this qualitative case study focuses on the action orientations 
of the opposing people, organizations, and interdependencies thereof.

Following McAdam and Boudet [19], the NIMBY category refers to single-point protests. In this context, judging the moral adequacy of the protests is irrelevant. However, it is of crucial importance whether the protesters oppose a planned overhead power line just in their village or, e.g., in the neighboring villages as well. Gaining insight to the protesters' action orientation supports the discussion of the main research question that was addressed here: Are the opposing organizations part of a social movement against grid extension? In Germany, the environmental movement had a major influence on the introduction of environmental policy and institutional changes to appear within the society [20]. Will the protests against grid extension become a creative power that will foster social change? Or are their activities rather motivated by individual concerns? In order to address these questions, it is not enough to examine the opponents' action orientations and the relationships between the opponent types. Indeed, it is also critical to understand the structure of the social fields where the conflicts take place.

To address these questions, the paper is structured as follows: First, the applied conceptual framework will be introduced, namely, the theory of strategic action fields by Fligstein and McAdam [21] and the social movement approach. Afterwards, qualitative and quantitative methodic approaches will be explained and the data is presented. In the next chapter, the results of five case studies of regional conflicts over power line projects will be presented, and the question as to whether the projects should be seen as a social movement will be discussed.

\section{Conceptual framework}

Organizations never act in a vacuum but in specific social contexts. One possibility would have been to conceptualize grid extension as an organizational field, applying a classic approach such as that of Paul DiMaggio and Powell [22]. This approach aims mainly at explaining stability by assuming that actors are so strongly tied to institutions and forced into routines that they do not have the capability to change things by their own will. The field of grid extension is, in fact, a conflicted one in which field actors clearly demand what they aim for and they are not determined in their action. Moreover, the future development of the field seems to open. Bourdieu [23, 24] also introduced a field concept that would be more suitable for this context: Conflicts over power resources within the field is highlighted. Numerous elements of Bourdieu's field theory have been taken up by Fligstein and McAdam [21, 25]. In their theory of strategic action fields, they explicitly aim to apply insights of social movement research. For this reason, strategic action fields (SAFs) was chosen as one of the main conceptual tools for this study. Thus, the grid extension conflict can be described as follows: The SAF consists of the protest organizations and critics who are considered as challengers. They possess few resources making it difficult for them to influence the development of rules and are thus relegated to the field's fringes. However, they wait for their chances to gain ground over the established group. Their opponents, powerful actors involved in the planning, advocating, and implementation of the grid extension projects, exert crucial influence on the design of the rules and dominate the field. These actors are called incumbents. This actor group mainly consists of the large operators of the transmission grid, the Federal Grid Agency, and the German government. Both actor groups try to improve their position in the field by acting strategically.

It is also important to mention that the conflict actually takes place in different fields. Moreover, an actor who is a challenger in one field might be an incumbent in another one. For example, in the federal state field, where legislative decisions about grid extension-federal laws-are made, regional states like Bavaria or Lower Saxony do clearly act as challengers. They represent the interests of the people living there against the federal government who want the grid to be extended as quickly as possible (see the constellation of EnLAG 2). Conversely, in the regional state fields, they represent the incumbents. Those fields are superordinated to the local fields where the power lines are planned because the grid operators have to observe prior rules that were made in state fields. This does not mean that the grid operators have no influence on the field rules. In fact, the grid extension plans of the operators-to a large extent-have gained a legislative status ${ }^{1}$.

To understand the dynamics of the conflict, it is important to look at its regional varieties. For some protest contexts, federal regulation is of minor importance because the challengers demand things that could be fulfilled by the incumbent project planners within the legal framework. Here, the local conflict fields would have to be considered primarily.

If the protesters' demands require legislative changes, state action fields on regional or federal level also have to be considered. Depending on the specific conditions, each regional conflict is characterized by a certain set of strategic action fields (SAF) that are relevant in that context. The results of the case studies serve to answer the subordinated research questions regarding the protest actors, their relationships, and the structure of the SAFs (see below).

On the basis of this "who's who" of grid extension opponents, the main research question as to whether the protests are part of a social movement shall be discussed. To achieve a better understanding of the protests, three approaches of social movement theory are applied: First, the 
framing approach by Blumer [26], who emphasized that movements concerned with existing problems arise only after pressure groups are successful in framing the issue as a social problem that can be influenced by public collective action. Following Benford and Snow [27], three conditions for the generation and the survival of a social movement must be met: defining a problem, identifying its causes, and attributing responsibility ("diagnostic frame"), proposing possible solutions or strategies of solutions ("prognostic frames"), and inviting people-often there is a special target group-to take part in public actions like demonstrations. Second, Rucht and Roth [28] assume that protests should develop social networks of actors who share a common vision of social change. Furthermore, the protest must be visible; action is necessary to display those visions. As stated above, in the regional protest areas, differently structured strategic action fields must be taken into account. In the "Discussion" section, it will be evaluated whether the protests are too heterogeneous to be interpreted as social movements. Third, there is a significant difference between NIMBY and NIABY (not-in-anyone's-backyard) [19]: In the German protest discourse, the term NIMBY has a bad connotation, e.g., because it accuses the protesters of being selfish. In contrast, McAdam and Boudet [19] use it in a rather descriptive sense, as an equivalent to local or single-point protests. It will also be discussed to what extent the differentiation between NIMBY and NIABY may help to understand the character of the grid extension protests.

\section{Methods}

This paper presents the results of a comparative qualitative case study that is based on a document analysis. The latter is supported by various literatures on the regional conflict situations [8-10]. The data set consists of more than 500 documents that are available on the Internet. A large share of these documents was published by the relevant actors themselves (press releases, planning documents, and open letters). An important addition is articles in the regional press that have been identified through a structured Internet search. The documents were published between 2004 and 2015. This long time span is justified by large asynchronicities that often exist between different regional protest activities. This is mainly caused by disparities in the planning procedures. In the EnLAG context, the first conflict (over the route EnLAG 2) started in 2004 in Lower Saxony. The first documented foundation date of a citizens' initiative against this project was the 27th of October in 2014. After a public meeting in Colnrade 172, people joined the interest group "Take care of high voltage" (local press, October 29, 2004). In contrast, the conflict over "South-East Passage" (project BBPIG 5) escalated in $2014^{2}$.

The quantitative document analysis was very useful in two respects: First, it helped to identify the main issues of the conflicts. The following Table 1 displays every demand that was articulated in more than 20 published documents. To guarantee the overarching character of each demand listed in Table 1, it was important to consider that a demand was not only advocated by one or a few but at least 15 challengers. Second, the quantitative analysis had a significant effect on the selection of regional cases.

\section{Case selection}

The selection of regional cases (see Fig. 1) was done based on the existence of a conflict that had achieved a minimum degree of attention in the public. This criterion was deemed fulfilled if at least 20 documents could be identified in which the challengers articulated relevant demands (see Table 1) with explicit reference to the region (representation). Moreover, for this context, the protests with a clear focus are especially interesting. For each one of the selected cases, there should be one or at maximum two demands that are represented significantly

Table 1 List of the core demands in the conflict field of German transmission grid extension

\begin{tabular}{|c|c|c|}
\hline Demand & $\begin{array}{l}\text { Number of } \\
\text { documents }\end{array}$ & $\begin{array}{l}\text { Number of different } \\
\text { actors }\end{array}$ \\
\hline Use of underground cable sections in a specific areas (1) & 71 & 42 \\
\hline General demand for participation in planning processes (2) & 47 & 37 \\
\hline Reserving grid extension for RET, not for coal plants or power treading (3) & 34 & 22 \\
\hline Use of new technologies to reduce the need for power lines or mitigate their negative effects (4) & 28 & 21 \\
\hline Fundamental opposition to the construction of a certain planned power line (5) & 24 & 16 \\
\hline Improvement of the transparency of the planning procedures (6) & 37 & 31 \\
\hline Opposition to power routes crossing nature preservation areas (7) & 37 & 32 \\
\hline Use of HVDC underground cable instead of HVAC overhead lines (8) & 28 & 22 \\
\hline Opposition to the construction of power lines if health protection cannot be guaranteed (9) & 37 & 26 \\
\hline $\begin{array}{l}\text { Cost calculations (the aspects of national economy should be ranked higher than short time } \\
\text { profitability) (10) }\end{array}$ & 28 & 22 \\
\hline
\end{tabular}




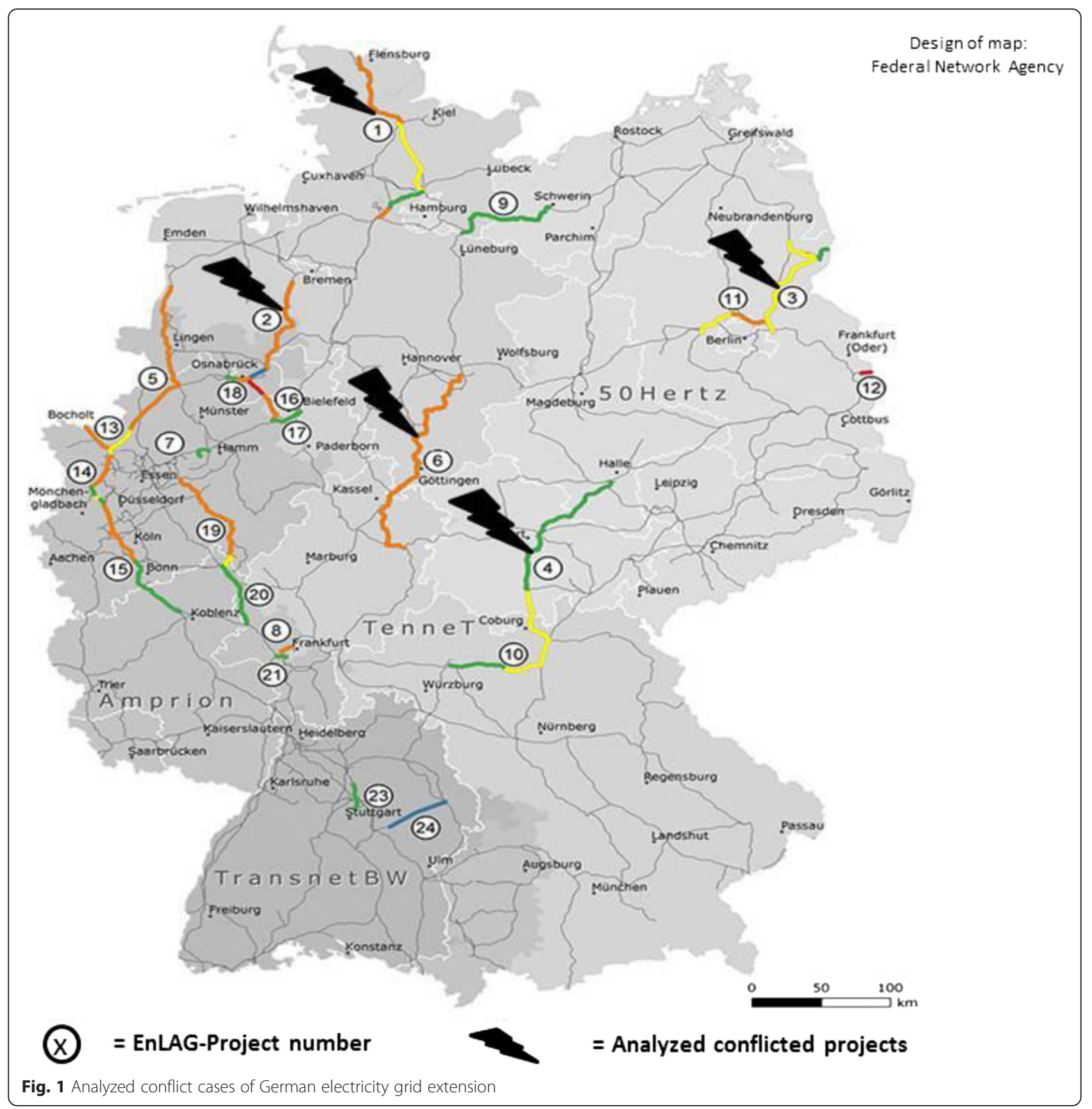

stronger than others (protest focus). The conflicts were only considered relevant if they lasted for longer periods (here, more than 2 years). Periods significantly shorter than this may not allow for stable protest actor structures to develop that are then viable for sociological analysis (continuity). These three criteria (representation, focus, and continuity) are fulfilled by the project nos. 1, 2, 3, 4, and 6 of EnLAG (see Table 2). It cannot, however, be ruled out that there are other EnLAG routes or "recently commenced projects" of the BBPIG (which began in 2013 or later) that may also fulfill the relevant criteria.
The list of demands illustrates the topics of the conflicts. Not every topic is of relevance for each region. Furthermore, not all demands are of the same relevance for this analytical context. For example, in demand number (2), "more participation" is a very important reason for the protests. But at the same time, it is too abstract and does not enable the observer to understand what should happen to resolve the conflict. In contrast, there are three demands that do provide satisfactory clarification on the situation: "not build at all/zero-option" (5), "underground cable section in conflicted areas" (1), and 
Table $\mathbf{2}$ Characteristics of the conflicted power line routes

\begin{tabular}{|c|c|c|c|c|c|}
\hline & EnLAG 1 & EnLAG 2 & EnLAG 3 & EnLAG 4 & EnLAG 6 \\
\hline Number of (considered) documents (representation) & 21 & 29 & 20 & 26 & 21 \\
\hline Period of conflict (continuity) & $2006-2014$ & Since 2004 & Since 2008 & Since 2006 & Since 2009 \\
\hline Protest Focus (demand number $(x)$ ) & (1) & (1) & $(1),(7)$ & $(3),(5)$ & (8) \\
\hline Original planned start of operation (year) Source [12] & 2010 & 2010 & 2010 & 2010 & 2015 \\
\hline Federal state & $\begin{array}{l}\text { Schleswig-Holstein, } \\
\text { Lower Saxony }\end{array}$ & $\begin{array}{l}\text { Lower } \\
\text { Saxony }\end{array}$ & Brandenburg & $\begin{array}{l}\text { Saxony-Anhalt, } \\
\text { Thuringia, Bavaria }\end{array}$ & $\begin{array}{l}\text { Lower Saxony } \\
\text { Hesse }\end{array}$ \\
\hline \multicolumn{6}{|l|}{$\begin{array}{l}\text { Number of documents where a demand is articulated for each } \\
\text { of the cases }\end{array}$} \\
\hline Use underground cable section in a specific area (1) & 9 & 17 & 10 & - & 4 \\
\hline General demand for participation in planning processes (2) & 4 & 4 & 7 & 4 & 5 \\
\hline $\begin{array}{l}\text { Reserving grid extension for RET, not for coal plants or power } \\
\text { treading (3) }\end{array}$ & 1 & 1 & 1 & 5 & 1 \\
\hline $\begin{array}{l}\text { Use of new technologies to reduce the need for power lines or } \\
\text { mitigate their negative effects (4) }\end{array}$ & - & - & 4 & 3 & 2 \\
\hline $\begin{array}{l}\text { Fundamental opposition to the construction of a certain } \\
\text { planned power line (5) }\end{array}$ & - & - & 1 & 6 & - \\
\hline $\begin{array}{l}\text { Improvement of the transparency of the planning } \\
\text { procedures (6) }\end{array}$ & - & 2 & 4 & 3 & 3 \\
\hline $\begin{array}{l}\text { Opposition to power routes crossing nature } \\
\text { preservation areas ( } 7)\end{array}$ & 1 & 5 & 6 & 2 & 6 \\
\hline $\begin{array}{l}\text { Use of HVDC underground cable instead of HVAC } \\
\text { overhead lines (8) }\end{array}$ & - & 3 & - & - & 17 \\
\hline $\begin{array}{l}\text { Opposition to the construction of power lines if health } \\
\text { protection cannot be guaranteed (9) }\end{array}$ & 5 & 3 & 5 & - & 6 \\
\hline $\begin{array}{l}\text { Cost calculations (the aspects of national economy should be } \\
\text { ranked higher than short time profitability) (10) }\end{array}$ & 1 & 2 & 4 & 2 & 4 \\
\hline
\end{tabular}

Source: own. Similar documents are excluded (see comment at Table 1)

"complete underground cable on the basis of HVDC technology" (8). Therefore, the qualitative case studies revolve around the challengers' position in reference to those specific demands. This partly theoretical justification of the interpretation of the protests is supported by the results of the quantitative analysis: For every regional case, one of these demands seems to have a crucial meaning (see Table 2). Furthermore, the assumption of a central meaning of the underground cable demand is justified by corresponding names of many protest organizations like "Pro underground cable," "Put high voltage down," and "No $380 \mathrm{kV}$ overhead line."

\section{Results}

The quantitative analysis provided valuable hints used to identify some very interesting conflict cases. But when it comes to discussion as to whether these protests should be considered as a social movement, it is necessary to have a closer look at the regional project opponents, their action orientations, relationships, strength, and the structure of the relevant fields. Doing so will help achieve a differentiated view on the challengers.

\section{Action orientations}

In this context, the action orientations of the challengers are defined by the efforts that incumbent actors have to provide to fulfill the core demand. If the protesters demand that underground cable be laid near their village, the conflict may be settled at the local level and their action orientations will reflect this. In this example, the opponents are not protesting against the project itself but rather only the concrete circumstances. Because conflicts like these can often be solved at the local level-without involvement of the legislator at the federal level-the protesters are seen as moderate or compromise-oriented. In the case of EnLAG 6, where challengers are demanding the entire route be wired and to use technical alternatives like high-voltage direct current (HVDC), there is a high degree of deviation from the legislative status quo necessary to meet the demands. In the case of EnLAG 4, the mainstream goal is to cancel the whole project (maximum deviation). Opposition fueled by potential health threats or other local reasons therefore usually call for moderate deviation from the status quo plans. High and maximum levels of deviation, on the other hand, are political in nature, involving 
energy- or climate-based demands. Without far-reaching reforms of the EnLAG, these demands cannot be fulfilled.

\section{Strength of regional protests-resources for action and regional expansion}

It is assumed that the resources of the protesters depend strongly on their presence along the planned route. Demonstrations and other public events (e.g., banner actions and podium discussions), as well as claims and lawsuits, increase public awareness and help ensure the support of municipal politicians. In terms of direct and targeted influence, protesters do not normally have the resources to make much of an effect-especially compared to grid operators, for example. Presence can be classified as either local, regional, or along the entire route. Local means that the protests concentrate on only one, or very few, locations. Regional means that there are several locations or smaller contiguous regions with civil protests. For the presence to be classified as being along the entire route, the protests have to fulfill three criteria: Protests must be observed in at least half of the length of the expansion route. Second, the local citizens' initiatives do not act separately but form a network which, for example, publish joint press releases and collectively signed open letters. Third, the main demands must refer to the whole route and not only to a short section of it.

\section{Three types of challengers}

Looking at the regional conflict constellations, on the side of the protesters, homogeneity is clearly a dominating characteristic. From region to region, in contrast, the protesters' orientations may differ widely (see above). Those actors who were motivated to begin protesting by a direct concern for the impact the expansion would have on the region are referred to as topic challengers. There are, however, other actors who are only indirectly involved in the regional conflicts but who support the protests in various ways and for various reasons. Taking a closer look at these other actors will help provide a better understanding of the protests in general. First, there are concept challengers who are-sometimes fundamentally-opposed to the grid extension plan. Second, there are acceptance challengers who have a specific interest in a speedy construction of the lines (see below).

\section{Topic challengers}

This type of challenger is denoted by a heterogeneous spectrum of actors who live in the concerned regions: The most important are the regional citizens' initiatives which are supported by local political actors in each case analyzed (see Table 3). Depending on the regional situation, other players like nature conservation groups and parents' organizations are also present in the field. Topic challengers' activities stem from an individual concern: a homeowner who is afraid of value losses; a mayor who does not want to be blamed for not having prevented an overhead line through the village; parents who are concerned that electromagnetic waves could have negative impacts on the health of their children. Action orientations like these usually correspond with rather moderate demands, typically involving the construction of underground cable sections. Another group of topic challengers justifies its protests for energy- and climate-based political reasons (e.g., "Build power lines with HVDV (high-voltage direct current) technology instead of alternating current!" or "New power lines only for renewable energy!"). These requirements correspond with action orientations of high or maximum deviation from the status quo.

Of course, the topic challengers lack the capability to have direct influence on the policy of grid extension. Nevertheless, they have important resources for action: organizing demonstrations and public discussions, giving public statements on licensing procedures, using the right to take legal action, and starting resolutions to influence regional policies more directly. Moreover, for several protest scenes, the relationship between citizens' initiatives and local politicians is a crucial element to explain changes from a bottom-up perspective: The protest group puts pressure on local politicians. The latter, in return, communicate the local conflicts and the lack of acceptance to their party colleagues, in particular those who are

Table 3 Challenger types-overview

\begin{tabular}{lll}
\hline & $\begin{array}{l}\text { Action orientation/Deviation from status quo: } \\
\text { moderate, high, maximum }\end{array}$ & Formal resources \\
\hline Topic challengers & $\begin{array}{l}\text { Moderate, high, maximum. Each topic challenger } \\
\text { has a strong regional focus and motivation. They have } \\
\text { specific interests in organizing protests against the power } \\
\text { lines. }\end{array}$ & $\begin{array}{l}\text { Performing high-profile activities like demonstrations. } \\
\text { Taking legal action, raising objections against planning } \\
\text { procedures, putting pressure on local politicians, } \\
\text { presence in medias }\end{array}$ \\
High, maximum. No direct self-interests. These actors are & Provide expert opinions, presence in the medias, \\
Acceptance challengers & and climate policy. & support topic challengers by providing arguments \\
& &
\end{tabular}


members of the government. Although the impact of most of these individual actions is rather small, over a longer period of time, the sum of these activities may significantly contribute to changing public discourses.

\section{Concept challengers}

The arguments and demands of this actor group are mostly independent of regional contexts. Their activity does not stem from individual concerns. Rather, these concept challengers criticize the basic assumptions of the grid extension plan (EnLAG). Depending on their specific targets, concept challengers usually have action orientations that correspond with a high or maximum degree of deviation. Three groups can be distinguished in the following way: environmental NGOs, political parties (Green and Left party actors at the state and federal level), as well as scientists. In their view, the EnLAG does not provide a democratic basis for grid extension. They express concerns that at least some of the new power lines will provide extra transmission capacity for conventional power plants, and that they are unnecessary for the distribution of purely renewable energies. Furthermore, they are often critical of the fact that new power lines may also extend possibilities for European energy trading. Finally, concept challengers argue that technical options for optimizing the existing power grid have not been implemented sufficiently.

\section{Acceptance challengers}

Between the incumbents on the one hand and concept and topic challengers on the other, another quite heterogeneous group exists. Actors within this group are not concerned with the specific EnLAG routes, but rather that the grid extension plan gets implemented. They are actors such as the German Bundesverband Windenergie (BWE) who represent the interests of the wind power sector and who seek to ensure that the production of wind power is not slowed down by a lack of grid capacity. They therefore can be seen as advocates for compromise. Another important group is the cable manufacturers. An important organization representing their interests, Europacable, advocates for underground cables. Put simply, more acceptance of grid extension projects means more cables sold. Table 3 provides an overview of the action orientations and resources of the different types of challengers.

\section{Field constitution between 2004 and 2007}

For the development of the protests and the conflict dynamics, the year 2005 is an important point of reference. That was when the German energy agency (dena) published its grid study [13] that is well known among the actors of the field and people who are interested in the development of the energy sector. This study brought the topic of the "necessary grid extension" onto the agenda and emphasized the intention to build the controversial projects. Although some protests started even before that (e.g., those against EnLAG 2 that began in autumn 2004), most initiatives were founded later. This variety of challengers did not exist from the beginning but has developed some years afterwards (until around 2007). This is also reflected by the diversification of SAFs: Whereas at the start of the protests, only the regional conflict fields existed, later on the state, SAFs on regional and federal levels became relevant for several route conflicts. One important example is the underground cable law in Lower Saxony (see below); another is the debate about the role of conventional power plants in eastern Germany for grid extension. In 2007, the economist Prof. Lorenz Jarass and the physicist Prof. Gustav Obermair presented their critical studies on the necessity of new power lines [29].

Apart from regional varieties, there are fluctuations at the local level: Some initiatives change their demands, disappear, or are reestablished. In total, however-and reflecting these varieties-there is a high level of continuity of the general protest constellation. The actor structure has become a complex entity: the protesters not only differ from region to region in their action orientations. To get a holistic picture, it is also important to consider actor groups that are only indirectly involved in the local conflicts but sometimes exert crucial influence on the developments. Moreover, the opponents partly have contradicting views on the conflicts (see below).

\section{Regional protest contexts as strategic action fields ${ }^{3}$}

The following paragraphs provide brief summaries of the main findings for the cases. Each regional case is structured as a set of strategic action fields. The basic (regional) SAF for each case is "Planning EnLAG x." Challengers are local protest groups, municipal politicians, and other organizations of the local protest. The group of incumbents includes transmission system operators (TSO) and their supporters on the regional level (e.g., research organizations who justify the TSO's plans). Furthermore, there are state action fields on country and federal levels. Depending on the conflict's specification, the state fields have to be considered as well. It is therefore important to notice that some of the conflicts take place in different areas. The SAFs cannot be described in detail here, but for dealing with the question whether the protests are a social movement, it is of primary importance to know in which SAFs the conflicts take place and how these are structured (Fig. 2).

\section{EnLAG no. 1}

(Kassoe/Denmark-Hamburg North-Dollern). There is only one protest focus on this route in the town of 


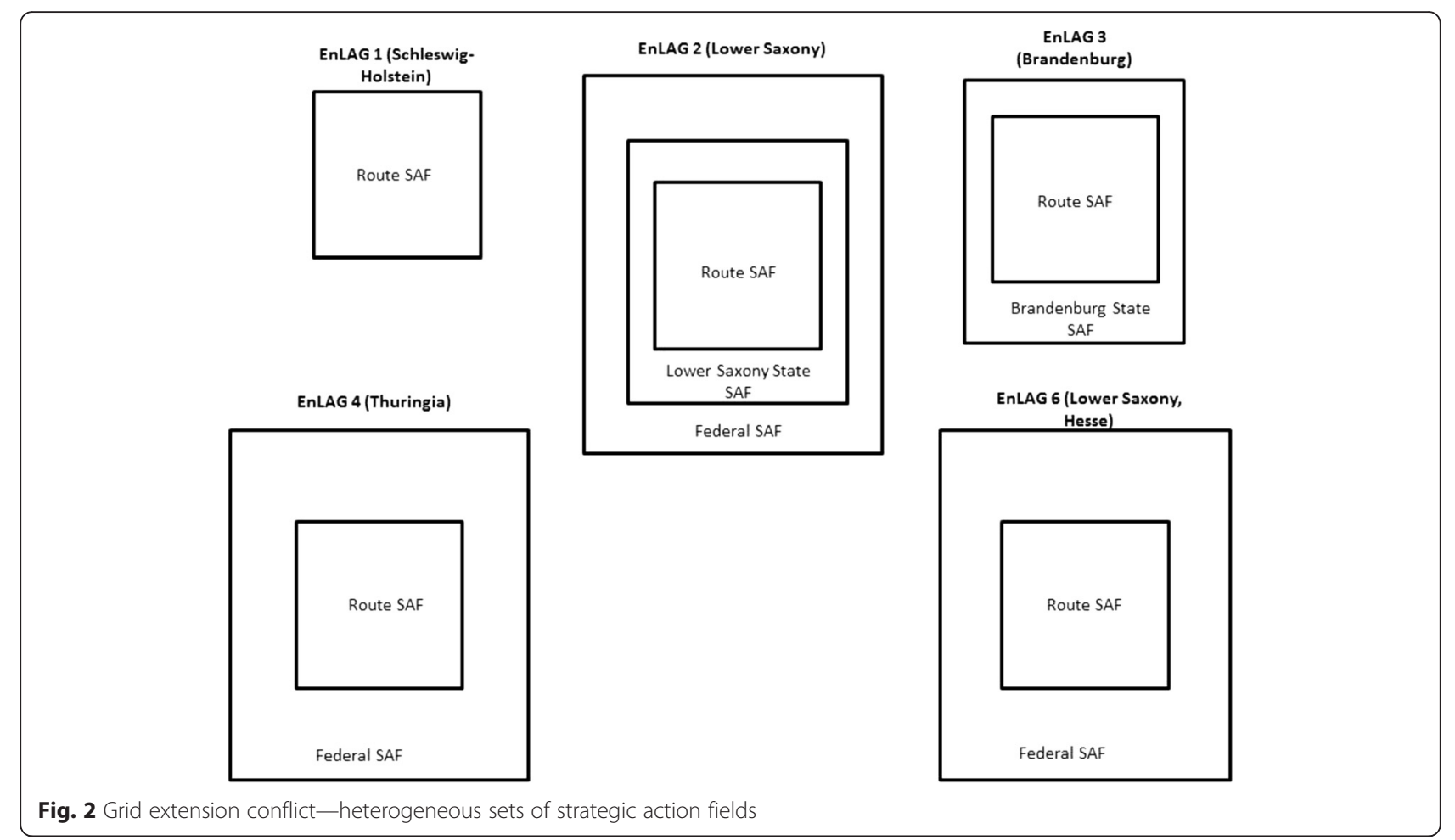

Quickborn (local protests). The main issue of contention involves a new overhead line that would pass a school at a distance of $90 \mathrm{~m}$ and some houses at $20 \mathrm{~m}$. The protesters demand this section of the route to be constructed as an underground cable or to maintain larger distances (moderate position). They do not oppose the project itself. Because of this, the conflict has remained at the local level. A compromise was found in March 2014 on the basis of ensuring the lines would be built slightly further away from the school and houses. The environmental minister of Schleswig-Holstein tried to mediate the dispute, but his role was not of particularly high relevance.

\section{EnLAG no. 2}

(Ganderkesee-Wehrendorf). There are several hotspots along EnLAG 2 where protest initiatives are active (regional spread). The predominating demand involves building several underground cable sections (moderate position). In addition to the regional SAF, the state SAFs on regional state and federal level are of high relevance here. In 2007, the government of Lower Saxony-as incumbent in the regional state SAF-reacted to the protests with the decision to introduce the "underground cable law" [30]. If transmission power lines cannot keep a distance of at least $400 \mathrm{~m}$ from residential areas, the government may force the TSO to use underground cable sections in these areas. Moreover, the underground cable law of Lower Saxony brought the federal state into opposition with the German government, who was not a proponent of this technology. In this way, the government of Lower Saxony became a challenger in the German state field of grid extension, where the federal government is the incumbent actor. This conflict may be resolved by the building of underground lines in contested locations.

\section{EnLAG no. 3}

(Neuenhagen-Bertikow/Vierraden-Krajnik/Poland). Similar to EnLAG 2, there are also several hotspots along the so-called "Uckermark route," e.g., the towns of Eberswalde and Angermünde, as well as some smaller villages. The situation is a bit more complicated than the one surrounding EnLAG 2 because there are also initiatives specifically opposed to the overhead line being built through a vast nature reserve (regional spread). Apart from the different motivations of the protesters, individual concern as well as nature conservation, there is a strong consensus in the rejection of overhead lines. Many actors explicitly demand the construction of underground cable sections (moderate position). The latter deman$\mathrm{d}$-although compromise-oriented-has caused the conflict to spill over into the regional state SAF: The protesters demand that the state of Brandenburg introduce an underground cable law like the one in Lower Saxony, but the regional government has so far refused this. So, the underground cable option is forestalled and the fronts 
are hardened in general. Compared with EnLAG 1 or 2, a compromise solution does not seem viable here.

\section{EnLAG no. 4}

(Lauchstädt-Redwitz). Like the situation regarding the EnLAG 3, protests by concerned citizens at the "Thuringian energy bridge" are also strengthened by environmental groups wanting to prevent the planned power line crossing the Thuringian Forest, but the protesters are much stronger here and their demands revolve around halting the construction of the power lines altogether (entire route, maximum deviation). Based on a scientific study financed by the initiatives, in cooperation with numerous municipalities and counties, the protesters argue that the power line would not be built for renewable energies but for the transport of surplus electricity produced by brown coal power plants. Thus, the protesters challenge the mainstream view of the federal EnLAG as an instrument that would support the transition to RET. The conflict also takes place in the Thuringia state field grid extension and the regional protest fields, but most important is the conflict within the federal SAF. Although the EnLAG enables the construction of underground cable sections here, a compromise solution does not seem likely.

\section{EnLAG no. 6}

(Wahle-Mecklar). There are strong protests against this route: Numerous local initiatives have formed networks via two umbrella organizations (entire route). The mainstream demand involves constructing the entire power line as an HVDC underground cable (high deviation). These demands are impossible to meet without a reform of the EnLAG. Therefore, the central area of this conflict is the federal SAF. EnLAG 6 is one of the planned routes to test underground cable sections. As it seems unlikely that the challengers are capable of pushing through the demand for HVDC, underground cable sections, as a compromise option, may dominate the conflict agenda in the future. If this does in fact come to pass, the regional SAFs (at the project level as well as the federal states of Lower Saxony and Hesse) will likely gain importance. This could represent an acceptable compromise for many of the concerned actors, while others, including a considerable share of the protesters, will likely be left unsatisfied.

\section{Summary of empirical case studies}

In Table 4, the main characteristics of the examined protest cases are displayed. In all cases, the initiatives are supported by local political actors: mayors, municipal parties, town, and community administrations, as well as district councils. The local protesters rely on scientific expertise to support their positions, which also provides additional arguments. It is apparent that some of these protest groups think and act locally. This means that protest actions can likely be stopped by moving forward with underground cable sections or diverting the routes

Table 4 Characteristics of the protests against the EnLAG

\begin{tabular}{|c|c|c|c|c|c|}
\hline Project (EnLAG number) & $\begin{array}{l}\text { Action resources/ } \\
\text { Regional expansion }\end{array}$ & $\begin{array}{l}\text { Important actors } \\
\text { (in addition to } \\
\text { citizens' initiatives) }\end{array}$ & $\begin{array}{l}\text { Action orientation/Level } \\
\text { of deviation from status quo }\end{array}$ & $\begin{array}{l}\text { Com-promise } \\
\text { likely or viable? }\end{array}$ & $\begin{array}{l}\text { Relevant Strategic } \\
\text { action field } \\
\text { (in addition to the } \\
\text { route-level SAF) }\end{array}$ \\
\hline Kassoe_Dollern (1) & Local & $\begin{array}{l}\text { Parents' organizations, } \\
\text { local parties, town } \\
\text { council of Quickborn }\end{array}$ & Moderate & Yes & - \\
\hline \multirow[t]{2}{*}{ Ganderkesee-Wehrendorf (2) } & \multirow[t]{2}{*}{ Regional } & \multirow[t]{2}{*}{$\begin{array}{l}\text { Oldenburg district council, } \\
\text { municipal councils }\end{array}$} & \multirow[t]{2}{*}{ Moderate } & \multirow[t]{2}{*}{ Yes } & $\begin{array}{l}\text { Regional state } \\
\text { level }\end{array}$ \\
\hline & & & & & Federal level \\
\hline $\begin{array}{l}\text { Neuenhagen—Bertikow/ } \\
\text { Vierraden—Krajnik (PL) (3) }\end{array}$ & Regional & $\begin{array}{l}\text { Barnin district council, town } \\
\text { councils of Angermünde } \\
\text { and Eberswalde, municipal } \\
\text { councils, local parties, nature } \\
\text { conservation organizations }\end{array}$ & Moderate & No & $\begin{array}{l}\text { Regional state } \\
\text { level }\end{array}$ \\
\hline Lauchstädt_-Redwitz (4) & Entire route & $\begin{array}{l}\text { Town council of } \\
\text { Großenbreitenbach, } \\
\text { municipal councils, Petra } \\
\text { Enders (mayor of } \\
\text { Großenbreitenbach), } \\
\text { economist Lorenz Jarass }\end{array}$ & Maximum & No & Federal level \\
\hline Wahle-Mecklar (6) & Entire route & $\begin{array}{l}\text { Schwalm-Eder-Kreis district } \\
\text { council, Nordheim district } \\
\text { council, local organizations } \\
\text { of conservative party, } 13 \\
\text { municipal councils }\end{array}$ & High & No & Federal level \\
\hline
\end{tabular}


towards neighboring villages instead. There are strong differences in the regional protest activities concerning the intensity of protests, their targets, and, linked to this, the probability of a compromise solution. In contrast to the other protest regions, in the case of EnLAG 1, there is only one protest focus at Quickborn. For EnLAGs 4 and 6 , especially strong networks among the regional actors can be observed. Also, the protests are the strongest in these two regions. The conflict over these routes cannot be solved that easily. There is a broad consensus at EnLAG 4, which is supported by the large majority of the protesters who demand that the project be canceled completely. However, in the other protest regions, the construction of underground cable sections might enable far-reaching agreements. Only strong topic challengers are able to carry the conflict into state action fields at either regional or federal levels. Whereas the federal SAF concerning EnLAGs 4 and 6 is mainly characterized by the central government refusing the challengers' demands, the federal SAF concerning EnLAG 2 is characterized by a state government in Lower Saxony that to some extent supports the protest actors, advocating for underground cable sections at the $380-\mathrm{kV}$ level.

\section{Discussion}

The following section addresses two issues: First, how can the relationships between the challenger types be characterized? Second, I return to the main research question. Taking into account the results of the challenger constellations, their relationships, and the heterogeneous structure of SAFs: In how far is it appropriate to speak of a social movement in the context of the protests surrounding grid extension?

\section{Relationships between challenger types}

The heterogeneity among the relevant SAFs is an expression of the various types of challengers' different and partly diverging orientations of action. To deal with the question of whether the protests are part of a social movement, it is important to establish a comprehensive understanding of the relationships between various challenger types. The main similarity linking the challenger types is that they criticize the EnLAG (and its basic assumptions) as a concept or they oppose the implementation of individual EnLAG routes (which can be based on different reasons). Beyond this, the challenger group is not a homogeneous block that works together to reach one common goal. Because of partly divergent interests and targets, the existence of latent inner contradictions has to be assumed. The following paragraphs analyze the extent to which the challenger types alternately support or, in some cases, even stand in contradiction to each other (see Fig. 3).

\section{Topic and concept challengers-mutual reinforcement}

Traditionally, concept challengers within the energy sector oppose the use of nuclear power, advocating a change to RET and decentralized energy supply. Environmental NGOs and parts of the Green and Left Parties, as well as critical scientists, have now found a new field of activity.

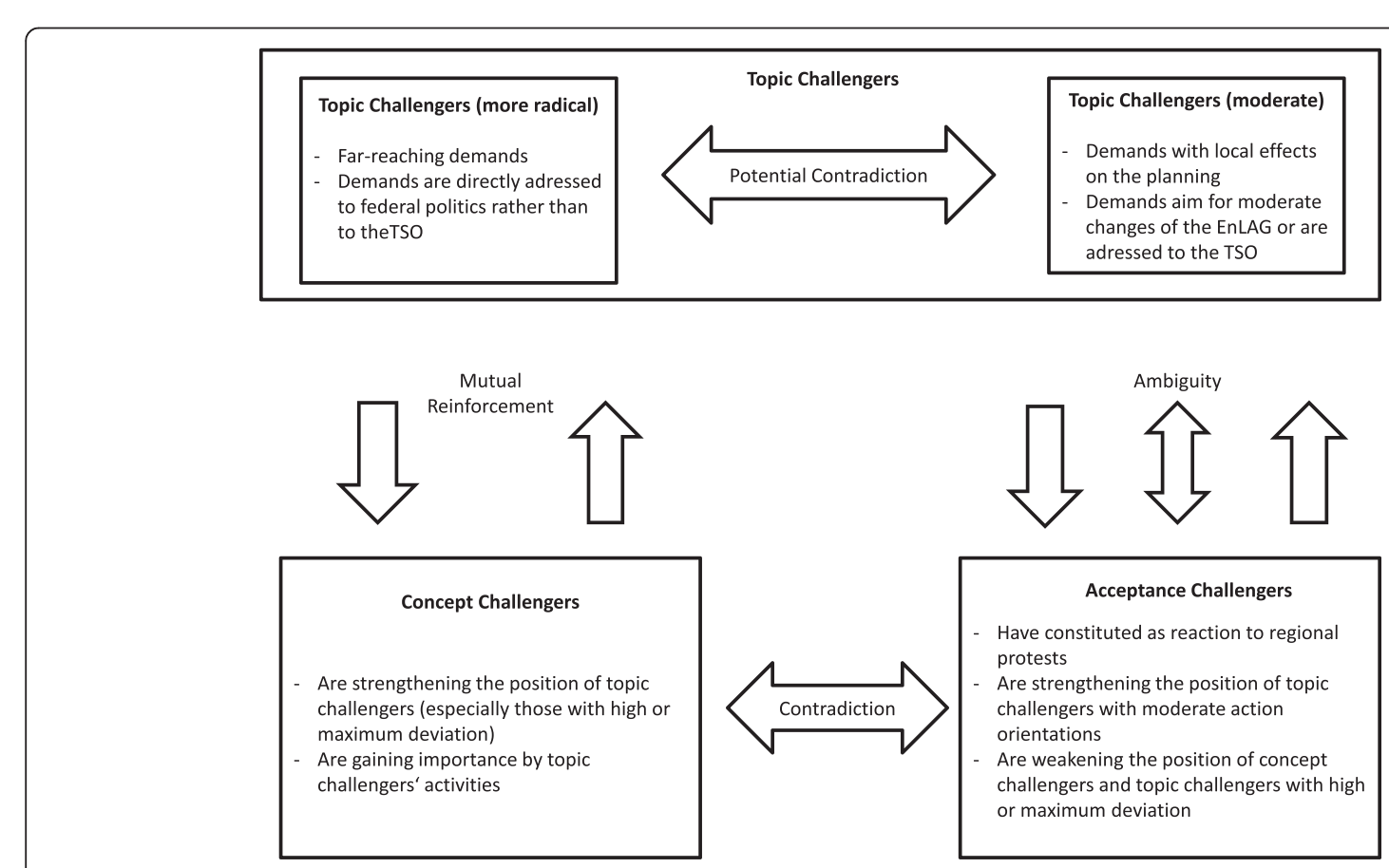

Fig. 3 Relationships between challenger types 
Their concept-critical analysis of the grid extension plan has only reached a broader public against the backdrop of the local protests. The feedback and the public attention motivated them to strengthen their activities in the field. On the other hand, the position of the topic challengers is supported by concept-critical arguments [9]. This knowledge strengthened the protests and helped the concerned citizens to reject NIMBY-related accusations.

There is a clear relationship of mutual reinforcement between both challenger types, although the relationship is not without some smaller inconsistencies. The demands of topic challengers with moderate action orientations can usually be fulfilled by constructing underground cable sections.

This way, for many people, objective and subjective disadvantages of new power lines can be avoided: No property value losses, no reduction in the quality of life, and no health threats for local people resulting from electromagnetic fields. As a result, the fulfillment of the moderate demands will likely expedite the whole planning process. In doing so, the goals of the concept challengers, which involve a complete revision of the grid extension plan, would be undermined. This contradiction, however, will remain theoretical in nature as long as neither group is successful at pushing through their demands.

Topic and acceptance challengers-mutual reinforcement of interests with moderate action orientations

To an even greater extent than the concept critics, the acceptance challenger is a challenger type of the second order that arises only as a result of the conflict. Without the continuous protest activities, there would have been no reason for acceptance challengers with specific interests in grid extension to support the initiatives, especially those with moderate orientations. In the gridextension conflict, regions with a preponderance of topic challengers with concept-critical orientations where the protesters aim to prevent the power line's construction, e.g., EnLAG 4, the endorsement of smaller amendments would probably not be helpful. To find a consensual solution within the EnLAG framework-which is usually the acceptance challengers' frame of reference-seems impossible here, with or without underground cable sections. Conversely, in the context of moderate protest environments, acceptance challengers might significantly contribute to the resolution of the conflicts and accelerate the planning processes. If they are successful as bridge builders, their position in different fields would be strengthened.

\section{Acceptance and concept challengers-contradiction}

For concept challengers, the question of how single EnLAG routes should be implemented is usually of minor importance. They oppose the EnLAG itself.
Therefore, they cannot be expected to support any modifications as small adjustments that would enable the acceleration of the planning processes.

Broadly speaking, the position of concept challengers is weakened by each constructed EnLAG route. Indeed, their activities are not making the situation easier for acceptance challengers and their arguments tend to support the topic challengers' position, especially those that are more radical. Thus, the relationship of these two challenger types is usually contentious.

\section{Grid extension protests as a social movement?}

Similar to the anti-nuclear, peace, and civil rights activists, the opponents of grid extension organize traditional protest activities like demonstrations, rallies, and public discussions. Blumer [26] emphasizes the role of protest activities within social movements. Pressure groups frame the grid extension as a social problem that can be overcome by "public collective action" (see above). On the one hand, the problem-"a new power line will be constructed near our homes"-is the same at each conflict site. On the other hand, the protesters often have different understandings of what is happening and explain the causes of grid extension in different ways. Thus, the opponents do not share one diagnostic frame. As a consequence, the proposed alternative solutions also differ. Thus, it would not be appropriate to talk of only one but, in fact, at least three prognostic frames that may differ from region to region (build underground section/build HVDC underground cable/cancel power line project).

Similarly, Rucht and Roth [28] consider "visible protest" as a necessary but not sufficient precondition for a social movement: "...not every protest is an expression of social movements. We can speak of movements if there is a network of groups and organizations that-based on a collective identity-secure a certain continuity of the protests. The actions are tied to the claim of shaping social change. They represent more than just saying no" (own translation). Social movements have common goals, beliefs, and interpretations that enable collective action [28].

Della Porta and Diani emphasize the relevance of networks among the members of a social movement [31]. Of course, networks among some of the initiatives do exist; some even extend across geographic regions. But more often than not, these networks are small and limited to protests against the same planned power route. Besides that, there is a considerable group of local initiatives that tend to act alone. Situated at the continuum's other end are the protests against EnLAGs 4 and 6. In terms of the diversity of diagnostic and prognostic frames, it seems hard to assume one collective identity among the protesters ${ }^{4}$. Another plausible interpretation of the protests should, however, be taken into consideration: The topic 
challengers are motivated by things happening nearby. Many protesters complain about a lack of participation and disrespect of their personal rights. The central topics usually revolve around: "grid extension as health threat," "real estate losing value," "modification of familiar environment." These topics may be summarized into the frame "missing participation." Still, this frame does not include alternative ideas or visions.

This may change if the concept-critical discourse would become hegemonic. Topic challengers with conceptcritical viewpoints do advocate for constructive alternatives. They do not just say no but also want to ensure that new power lines are actually planned for a fast and effective transition to RET. Overall, they are closely related to the environmental, climate, and anti-nuclear movements. However, this is only a tendency. Currently, it is unclear whether this tendency continues to gain momentum or if the protests will be pacified by smaller modifications.

Apart from the openness of the further development, how can the protests of today be characterized? Obviously, there is a large gap between rather disconnected singlepoint protests and those with the clear characteristics of a social movement. The first-reflecting the critical discussion on the NIMBY concept (see above) - might be adequately characterized by the "neutral" definition of the NIMBY term from McAdam and Boudet [19]. They use it in a descriptive sense to define local or single-point protests. Referring to the analyzed cases in this way can be categorized at most two out of five protests (EnLAGs 1 and 2), but what about the rest-the topic challengers who are inspired by concept-critical positions? Demands like "Underground cables for the whole route (but not only at our village)!" and "No power lines for coal!" seem to correspond well with the concept of NIABY (not-inanyone's-backyard) [19] (see "Conclusions" section).

\section{Limitations and outlook}

The study of the analyzed cases displays the heterogeneous character of the protests against grid extension. It provides an overview on the diversity of actor types and strategic action fields. Moreover, the character of the grid extension protests was discussed in the context of social-movement-theory approaches. Two limitations of the results should be mentioned here: First, the statements on the previously presented (most conflicted) cases may not necessarily be transferable to the protests as a whole. This study also implements empirical analyses on further protests against other power line projects concerning EnLAG [12] and BBPIG [32], but a holistic analysis of all grid extension projects remains absent. Second, the results are only valid for the time span up to 2014. New protests against the large HVDC transmission lines ("Strom-Autobahnen")-under BBPIG regulation-are arising in different parts of Germany, but because of insufficient empirical information, the second wave of protests could not be taken into consideration for this paper. The data collection for this study was almost finished before the new conflicts escalated. The latter should become the object of further research. In order to get a better understanding of the field dynamics, it will be of special relevance to also consider the other side: How do the incumbents deal with the conflict and which strategies do they use? These are also important topics of further research.

\section{Implications for practice}

The German government aims to transform the energy system to RET. Compared to different technologies of energy storage, grid extension is regarded as the cheapest way to transform the energy system to RET. If only a few power lines will be built, more storage capacities are needed and the transformation process may become more expensive. The protests arose for two main reasons: a perceived lack of participation in the planning process and a lack of trust in the government to implement grid plans to transport wind- and solar-based energies. To solve this conflict, the government should do two things: first, phase out coal. In 2011, shortly after the nuclear disaster in Japan, chancellor Merkel announced her government's intent to end nuclear power use by 2022. This step was given credibility because it was combined with the decommissioning of several older reactors. For the remaining reactors, a clear timetable for their decommissioning was presented. Today, comparable action should be taken with regard to the coal sector. Furthermore, the exploitation of new lignite mines has to be stopped. In accordance with the climate policy goals, the last German coal power plant should be turned off no later than 2040. Second, the government should build more underground cables. In Lower Saxony, transmission power routes must keep a distance of at least $400 \mathrm{~m}$ from residential areas. Otherwise, the regional government may demand the planner to construct that section as underground cable. This regulation should become a blueprint for the planning procedures in other regions.

\section{Conclusions}

Among both the local topic challengers as well as in terms of the whole action field of grid extension, there are actors with strongly differing and partly even diverging action orientations. This heterogeneity is mirrored by the structure of the regional conflicts which can each be interpreted adequately as a set of strategic action fields. Where the local challengers usually have moderate demands and the conflict is limited to a single or a few geographical locations, the conflict takes place mainly at route level (EnLAG 1). Conversely, conflicts with concept-critical issues at the top of the agenda also 
take place usually within the federal SAF (EnLAG 4, EnLAG 6). The complex set of SAFs in the conflict over EnLAG 2-including route-, as well as regional-, and federal-state levels-is significant. As a challenger in the federal state field, the Lower Saxony government partly advocated for the protest initiatives. It thus paved the way for the option of a constructive solution. In light of the more radical demands regarding the EnLAG 4 and 6 conflicts, it was quite unlikely that the regional governments would play a similar role. It is therefore unsurprising that the regional-state level is "missing" in those SAF sets.

The picture presented here of heterogeneous actor structures and conflicting SAF sets supports the thesis that the grid extension protests are not a social movement-at least not during the period from 2004 to 2014. At the same time, it would be incorrect to consider the totality of the protests as a universe of isolated, singlepoint protests: both trans-project networks as well as NIABY-based demands provide evidence that a certain level of coherency between the various protest groups exists. In the end, the grid extension protests can be seen as an aggregation of single-point or single-region protests that are at times dominated by a NIMBY, at other times a NIABY character, and that are connected only loosely both internally and externally.

\section{Endnotes}

${ }^{1}$ For details, see the results of the grid extension study that was edited by the German energy agency in 2005 ("dena I") [13]. The study was mainly financed and conducted by the transmission grid operators. Every transmission power line project that was claimed to be necessary for the energy security in "dena 1" later received a legal status within the framework of the Power Line Extension Law of 2009 [12].

${ }^{2} \mathrm{HVDC}$ corridor D is one of 36 other power line projects to be constructed under the BBPLG regulation [32].

${ }^{3}$ For more detailed descriptions of the protest contexts, see Neukirch (2014) [33].

${ }^{4}$ The grid extension protests seem to confirm the assumption of a correspondence between the diagnostic and prognostic frame: "In other words, the identification of specific problems and causes tends to constrain the range of possible "reasonable" solutions and strategies." [27].

\footnotetext{
Abbreviations

BBPIG: Bundesbedarfsplangesetz; BWE: Bundesverband Windenergie; Dena: Deutsche Energieagentur; EnLAG: Energieleitungsausbaugesetz; HVAC: high-voltage alternating current; HVDC: high-voltage direct current; NIABY: not-in-anyone's-backyard; NIMBY: not-in-my-backyard; RET: renewable electricity technologies; SAF: strategic action field; TSO: transmission system operator.
}

\section{Competing interests}

The authors declare that they have no competing interests.

\section{Authors' contributions}

MN solely wrote the manuscript, and he read and approved the final version.

\section{Authors' information}

MN is currently employed as a research fellow at the Institute of Social Sciences of the University of Stuttgart in Germany. The study presented here is part of a project funded by the Helmholtz-Gemeinschaft (see "Acknowledgements"). MN is especially interested in processes of sociotechnical transition. In 2010, he published his doctoral thesis on the international pioneer phase of wind power use.

\section{Acknowledgements}

This study was supported by the Helmholtz Association and the University of Stuttgart. The research has been conducted as a part of the Alliance Energy-Trans "Future infrastructures for meeting energy demands. Towards sustainability and social compatibility." I am grateful for many helpful comments and support with the translation by Gerhard Fuchs, Ulrich Dolata, Ulrike Fettke, and the reviewers. Special thanks go to Elke Ristok for the final correction.

Received: 18 March 2015 Accepted: 6 January 2016

Published online: 23 February 2016

\section{References}

1. Neukirch M (2010) Die internationale Pionierphase der Windenergienutzung, Dissertation, University of Göttingen

2. Mautz R, Byzio A, Rosenbaum W (2008) Auf dem Weg zur Energiewende. Die Entwicklung der Stromproduktion aus erneuerbaren Energien in Deutschland. Universitätsverlag Göttingen, Göttingen

3. Mayntz R, Hughes TP (eds) (1988) The development of large technical systems. Campus, Frankfurt a. M

4. Geels F, Fuchs G, Hinderer N, Kern F, Kungl G, Neukirch M, Wassermann S (2015) A reformulated and differentiated transition pathways typology. Illustrated with a comparative multi-level analysis of the German and UK low-carbon electricity transitions (1990-2014)., Submitted paper at Research Policy, September 8, 2015

5. Federal Grid Agency (2014) Netzentwicklungsplan Strom 2013 und Offshore-Netzentwicklungsplan 2013 bestätigt., Press Release, January 8, 2014. http://www.bundesnetzagentur.de/SharedDocs/Downloads/DE/ Allgemeines/Presse/Pressemitteilungen/2014/140108_NEPStrom2013.pdf?_ blob=publicationFile\&v=4. Accessed December 21, 2015

6. Federal Grid Agency (2015) http://www.netzausbau.de/leitungsvorhaben/de html. Accessed December 21, 2015

7. Bruns E, Futterlieb M, Ohlhorst D, Wenzel B (2012) Netze als Rückgrat der Energiewende. Hemmnisse für die Integration erneuerbarer Energien in Strom-, Gas- und Wärmenetze. Universitätsverlag, Berlin

8. Rau I, Schweizer-Ries P, Zoellner J (2010) Umweltpsychologische Untersuchung der Akzeptanz von Maßnahmen zur Netzintegration Erneuerbarer Energien in der Region Wahle-Mecklar (Niedersachsen und Hessen). Abschlussbericht, Saarbrücken

9. Schnelle K, Voigt M (2012) Energiewende und Bürgerbeteiligung. Öffentliche Akzeptanz von Infrastrukturprojekten am Beispiel der "Thüringer Strombrücke". Study on behalf of Germanwatch e. V., DAKT e. V. Heinrich-Böll-Stiftung, Thüringen

10. Zimmer R, Kloke S, Gaedke M (2012) Der Streit um die Uckermarkleitung - eine Diskursanalyse. Studie im Rahmen des UfU-Schwerpunktes "Erneuerbare Energien im Konflikt". Herausgegeben vom Unabhängigen Institut für Umweltfragen e.V, Berlin

11. Bundesministerium für Umwelt, Naturschutz und Reaktorsicherheit (2011) Das Energiekonzept der Bundesregierung 2010 und die Energiewende 2011

12. EnLAG (2009) Gesetz zum Ausbau von Energieleitungen (EnLAG) vom 21. August 2009. Bundesgesetzblatt Teil I: 2870

13. dena (2005) dena-Netzstudie I. Endbericht, Köln

14. Friends of the earth (2014) Stromnetzplanung muss auf den Prüfstand. Vor allem die Ost-Süd-Stromtrasse nach Bayern., Press Release, November 21, 2014 http://www.bund.net/nc/presse/pressemitteilungen/detail/artikel/ strom-netzplanung-muss-auf-den-pruefstand-vor-allem-die-ost-suedstromtrasse-nach-bayern/. Assessed December 21, 2015

15. Friends oft he earth Bavaria (2015) Bund Naturschutz und Bürgerinitiativen fordern endlich eine dezentrale Energiepolitik für Deutschland., Press Release, August 19, 2015 http://www.stromautobahn.de/wp-content/uploads/2015/08/ 
PM-073-15_BUND-Naturschutz-und-B\%C3\%BCrgerinitaitiven-forderndezentrale-Energiepolitik.pdf. Assessed December 21, 2015

16. Lenkert R (2014) Speaker for environmental policy, Bundesfraktion Die Linke: Geplanter Netzausbau ist unnötig und falsch., Press Release, November 4, 2014 http://www.linksfraktion.de/pressemitteilungen/geplanter-netzausbauunnoetig-falsch/. Assessed December 21, 2015

17. Hirschhausen C (2013) Acht Fragen an Christian von Hirschhausen. "Keine Stromautobahnen für Kohlekraftwerke" DIW Wochenbericht $20+21$., p 13

18. Batel S, Devine-Wright P (2015) A critical and empirical analysis of the national-local 'gap' in public responses to large-scale energy infrastructures. J Environ Plan Manag 58(6):2015

19. McAdam D, Boudet HS (2012) Putting social movements in their place. Explaining opposition to energy projects in the United States, 2000-2005. Cambridge University Press, Cambridge

20. Weiland S (2007) Politik der Ideen. Nachhaltige Entwicklung in Deutschland, Großbritannien und den USA. VS Verlag für Sozialwissenschaften, Wiesbaden

21. Fligstein N, McAdam D (2011) Towards a general theory of strategic action fields. Sociol Theory 3:1-26

22. DiMaggio P, Powell W (1983) The iron cage revisited: institutional isomorphism and collective rationality in organizational fields. In: American Sociological Review, vol 48., pp 147-160

23. Bourdieu P (1983) Ökonomisches Kapital, kulturelles Kapital, soziales Kapital. In: Kreckel R (ed) Soziale Ungleichheiten. Otto Schwartz, Göttingen

24. Bourdieu P (2005) The social structures of the Economy. Polity Press, Cambridge

25. Fligstein N, McAdam D (2012) A theory of fields. University Press, Oxford

26. Blumer H (1971) Social problems as collective behavior. Soc Probl 18:298-306

27. Benford R, Snow A (2000) Framing processes and social movements. An overview and assessment. Annu Rev Sociol 26(2000):611-639

28. Rucht D, Roth R (2008) Die sozialen Bewegungen in Deutschland seit 1945. Ein Handbuch. Campus, Frankfurt/M

29. Jarass L, Obermair GM (2007) Notwendigkeit der geplanten 380kVVerbindung Raum Halle - Raum Schweinfurt (Südwestkuppelleitung). Kurzfassung, Wiesbaden

30. Underground Cable Law of Lower Saxony (2007) Niedersächsisches Gesetz über die Planfeststellung für Hochspannungsleitungen in der Erde vom 13. Dezember 2007. Niedersächsisches Gesetz- und Verordnungsblatt No. 40/2007., p 709

31. Della Porta D, Diani M (1999) Social movements. An introduction. Basil Blackwell, Oxford

32. BBPIG (2013) Gesetz über den Bundesbedarfsplan (Bundesbedarfsplangesetz - BBPIG)., Date of Execution: July 23, 2013

33. Neukirch M (2014) Konflikte um den Ausbau der Stromnetze. Status und Entwicklung heterogener Protestkonstellationen. Stuttgarter Beiträge zur Organisations- und Innovationssoziologie 2014-01

\section{Submit your manuscript to a SpringerOpen ${ }^{\circ}$ journal and benefit from:}

- Convenient online submission

- Rigorous peer review

- Immediate publication on acceptance

- Open access: articles freely available online

- High visibility within the field

- Retaining the copyright to your article 